\title{
French researchers brace for budget cuts
}

Paris. For the first time in ten years, the French government is proposing to decrease the level of funding for civilian research. Proposals submitted to parliament last week envisage a reduction of 1.4 per cent next year - or 3.3 per cent in real terms, taking inflation into account - from FFr53.1 billion (US $\$ 10.3$ billion) to FFr52.3 billion (US $\$ 10.2$ billion).

This proposed reduction will have relatively little impact on publicly funded research establishments, and has so far generated relatively little reaction from researchers and their unions, partly because it was not unexpected. But proposals from the state secretary for research, François d'Aubert, to tackle the problem of recruiting young researchers have done little to allay concern among scientists still reeling from a freeze imposed last year.

Funding for European-level laboratories, such as the European Molecular Biology Laboratory and the European Southern Observatory, will be reduced by a total of 3.14 per cent. This echoes a similar decision by the German government in late July (see Nature 382, 285; 1996). France's contribution to the European Laboratory for Particle Physics (CERN) is likely to be reduced by about 2 per cent to FFr700 million, according to officials.

Faced with a need to reduce the public deficit, Alain Juppé, the prime minister, has decided to achieve this through cuts in government spending. Total spending will now be FFr1,553 billion next year - the same in current francs as last year, despite an expected rate of inflation of 1.9 per cent. In recent years government spending has been increasing by 4 per cent a year on average.

Almost all government ministries have had to make cuts. But a few have been spared, and the Ministry of National and Higher Education, which has responsibility for research, is one. With a total budget of FFr324.2 billion, it will benefit from an increase of just over 2 per cent.

Research will not share this overall growth. Nevertheless, Dominique Poiroux, d'Aubert's chief of staff, says that it remains a high priority for the government. $\mathrm{He}$ points out that the reduction in the research budget will primarily fall on industrially related research and aeronautics - which will receive FFr360 million less than this year. Many of the research programmes in aeronautics have been completed.

In industrial research, new initiatives may offset the loss of funds. ANVAR, the agency responsible for innovative companies, will see its budget reduced by FFr150 million, but the creation of investment funds' along American lines will help to divert private capital to such companies.

"The important thing is to preserve publicly funded research, and the operating resources of our laboratories," says Poiroux. $\mathrm{He}$ adds that support for programmes, which, when combined with incentive funds and equipment funds, make up laboratory resources, should increase by 3.1 per cent compared to 1996 for government research establishments.

But as far as their overall budgets including staff costs - are concerned, not all government laboratories are in the same boat. The budget of the Centre Nationale de la Recherche Scientifique (CNRS), the main supporter of basic research, will grow in current francs to FFr13.45 billion, an increase of 1.12 per cent. That of the medical research agency, INSERM, will stay the same as last year, while ORSTOM, which is responsible for research in developing countries, will see its budget fall by 1.8 per cent.

In contrast, bodies responsible for national strategic priorities - space and nuclear - will have their budgets maintained, with a slight increase for the Atomic Energy Commission. The space agency CNES will as a result be able to meet

\section{Swiss cull to meet fears of BSE}

Basel. Switzerland's government announced last week that it has decided to subsidize the slaughter of 230,000 cows born before 1 December 1990 to restore the faith of consumers in Swiss beef. Feeding calves with animal protein, considered to be responsible for transmitting bovine spongiform encephalopathy (BSE), was legal until 1990.

Farmers will receive SFr1,000 (US\$800) compensation for each cow slaughtered, and their use for human consumption will be banned. "This move is intended to restore to Switzerland the status of a BSE-free country," said the economics minister, JeanPascal Delamuraz.

BSE has already caused a serious economic problem for Swiss farmers. The domestic market has fallen by a third since the beginning of the year, leading to reduced beef prices and the decision to store large quantities of meat. Foreign markets have also been blocked, as the European Union - of which Switzerland is not a member has banned the import of Swiss beef. The ban followed an announcement in March by the British government of a possible link between BSE and Creutzfeldt-Jakob disease in younger patients.

Switzerland has the second highest incidence of BSE in Europe, although, at 9.5 cases per 100,000 cattle, this is only one-hundredth of the UK level. "We intend to remove from the human food chain the entire cattle population which has a statistical chance of harbouring BSE-infected animals," says Heinz Mueller, a spokesman for the federal veterinary agency. its international commitments, in particular to the space station, and to pay its share of the costs resulting from the loss of the first Ariane-5 launch.

University research, for which d'Aubert has often expressed concern over its relatively poor performance, also turns out to be one of the winners. Despite the overall budget austerity, it will receive 3.15 per cent more than last year.

D'Aubert wants to address the problem of the recruitment of researchers head on. "Research bodies are being strangled by their staff costs, which are continuing to grow at the expense of operating funds," says Poiroux.

The government's solution appears simple: the rate of recruitment will be fixed at 2.5 per cent of the total staff number, and measures will be introduced to encourage researchers to take up posts in universities or industry. If more positions are freed than there are recruits, the excess posts will be eliminated, and the money used for operating costs.

Catherine Tastemain

\section{IMAGE UNAVAILABLE FOR COPYRIGHT REASONS}

Better beef? The Swiss slaughter focuses on cows that may have been fed animal protein.

According to Mueller, the recent study by Roy Anderson and his colleagues at the University of Oxford showing that culling is likely to have only a limited impact on the extinction of BSE in the United Kingdom (see Nature 382, 779; 1996) is not relevant to Switzerland, as the objectives of the two countries are very different. "We want to rebuild trust in Swiss beef as soon as possible," he says.

The remains of Swiss cows born before 1990 will be used in animal feed given to pigs. But this is likely to cause problems. The two leading supermarket chains, Migros and Coop, announced last month that, in order to restore public trust in their products, they will stop selling meat from any species that is raised on feed containing animal protein.

Oliver Klaffke 